\title{
Study on lamp-layout scheme of highway tunnel lighting based on DIALuX
}

\author{
SHI Na,DONG Lili,QIN Li,XU Wenhai \\ Photoelectric Laboratory, School of Information Science and Technology, Dalian Maritime \\ University, Dalian 116026, China
}

\begin{abstract}
Keywords:tunnel lighting;lamp-layout;DIALux;highway tunnel
Abstract:Aiming at the traffic safety and comfort issues of the tunnel lighting system,In this paper, taking the case of ChiBai Tunnel in Tonghua of Jilin Province and HeDa Expressway ShiDao-YangCha tunnel,different installation methods,installation height,installation angle, and different combination of lighting power and the installation space with the same power in unit length are simulated by using DIALux software.Through the comparison and analysis of average road surface illumination and the evenness data obtained from two tunnel simulation tests, it can find out the best scheme of the tunnel lighting,to provide reference for reasonable design and configuration of tunnel lighting.
\end{abstract}

\section{Introduction}

In order to ensure the visual demand of drivers in the tunnel, the brightness of the tunnel is needed.According to regulations in the "Rules of Highway Tunnel Lighting Design"(JTG/TD70/2-01-2014) released in July 2014 by the department of transportation ${ }^{[1]}$,the tunnel with a length of more than $100 \mathrm{~m}$ should be equipped with lighting facilities, and highway tunnel lighting design should be incorporated into the overall design of the tunnel.Tunnel lighting directly affects the safety and energy conservation of tunnel operation ,making the design of tunnel lighting system become an important part of highway tunnel design.

In highway tunnel lighting design,we need to calculate the tunnel surface illumination and evenness of the tunnel entrance section, transition section, middle section and exit section,to determine the optimal lamp-layout mode in each tunnel section.In order to solve the calculation problem of the tunnel lighting system,DIALux software is selected as the lighting simulation software to simulate the tunnel lighting space.The software has been widely used in the design of the tunnel lighting system in many papers, which is easy to operate and can test accurately,providing a great help in the early design of the tunnel lighting ${ }^{[2-4]}$. The tunnel lighting design of ChiBai Tunnel in Tonghua of Jilin Province and HeDa Expressway ShiDao-YangCha tunnel are respectively respectively simulated, analysising and comparing the results data of lighting installation mode, installation height, installation angle and combination of lighting power and the installation space with the same power in unit length,to get the best project of lighting installation.

\section{Tunnel Lighting Simulation Model}

We select the middle section of ChiBai Tunnel in Tonghua of Jilin Province and the entrance section of HeDa Expressway ShiDao-YangCha tunnel to make a simulation. Where in the middle section of ChiBai tunnel is $78 \mathrm{~m}$ long, $10.5 \mathrm{~m}$ wide and $7.45 \mathrm{~m}$ high. The entrance section of ShiDao-YangCha tunnel model is $48 \mathrm{~m}$ long, $10.5 \mathrm{~m}$ wide and $5 \mathrm{~m}$ high. We adopt LED lamp and HPS(high pressure sodium) lamp. The rate power of the LED lamp is $180 \mathrm{~W}$, the real power is $182.5 \mathrm{~W}$.The whole lights' luminous flux is $15520 \mathrm{~lm}$. The rate power of the HPS lamp is $420 \mathrm{~W}$, the real power is $429.9 \mathrm{~W}$. The whole lights' luminous flux is $30845 \mathrm{~lm}$. The distribution curve flux of the lamp is shown in Figure 1 and Figure 2. The light distribution of C0-180 and C90-270 is axial symmetry with the light.We adopt the DIALux as simulation software. The software adopts Global 
illumination algorithm ${ }^{[5]}$.In the software, we establish the space model of the tunnel. The inner surface is made of cement material, the albedo is $30 \%$. The computing models are shown as Figure 3 and Figure 4. The width of the two tunnel model is same. The length and height, the lamp types and the combination of lamps with different power is different. Where in the lamps arrangement in the basic section of ChiBai tunnel model is easy,the lamps arrangement in theShiDao-YangCha tunnel entrance section is complicated.

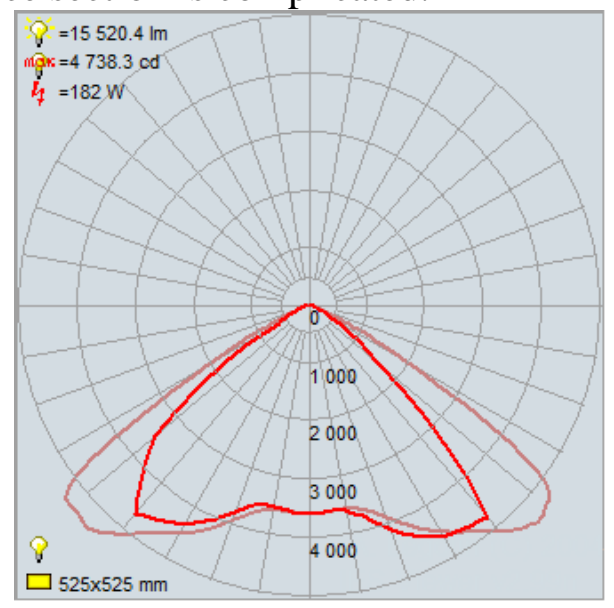

Figure 1 The distribution curve flux of LED lamp

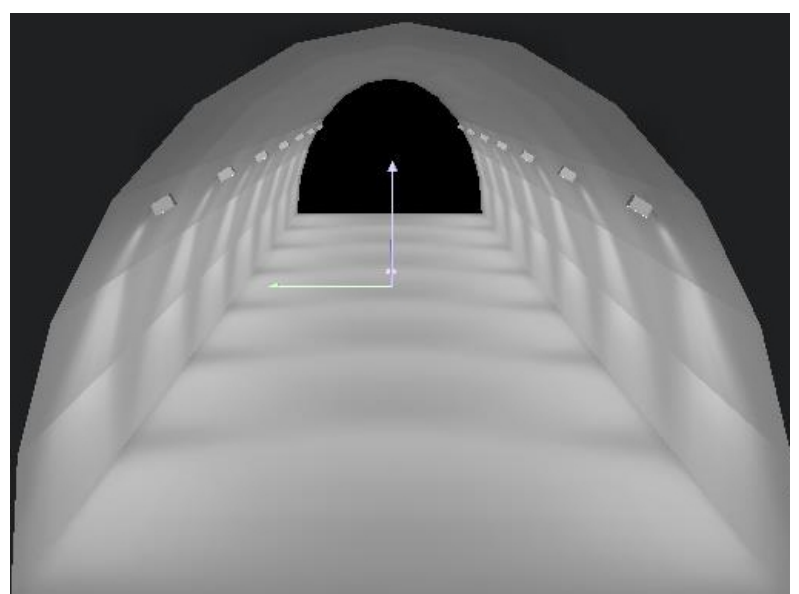

Figure 3 Modle of the middle section of ChiBai Tunnel

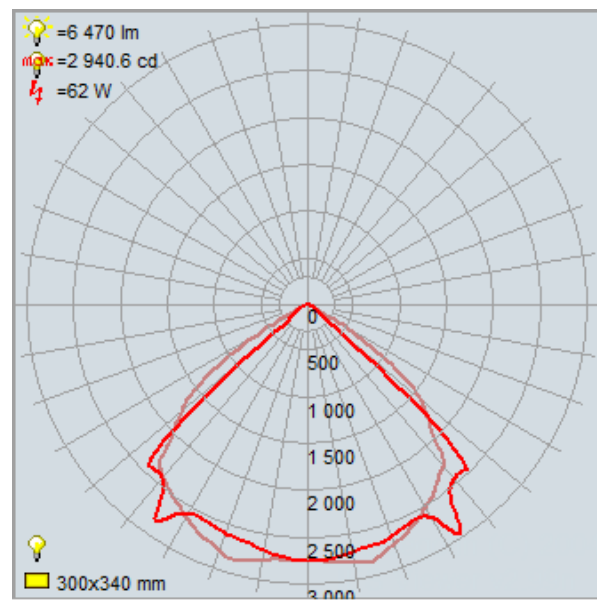

Figure 2 The distribution curve flux ofHPS lamp

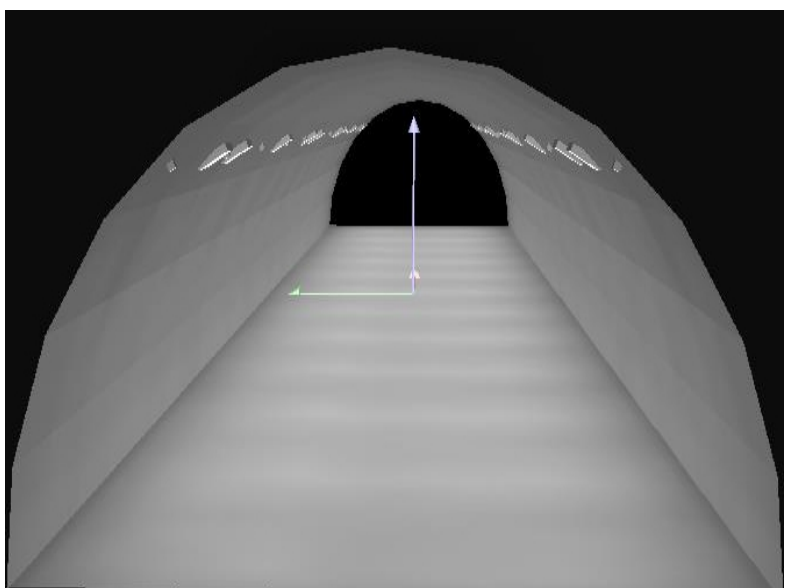

Figure 4 Modle ofthe entrance section of $\mathrm{HeDa}$ Expressway ShiDao-YangCha tunnel

Figure 5 and Figure 6 show the pseudo color image in the better situation and worse situation of the Lamps and lanterns setting illumination respectively.

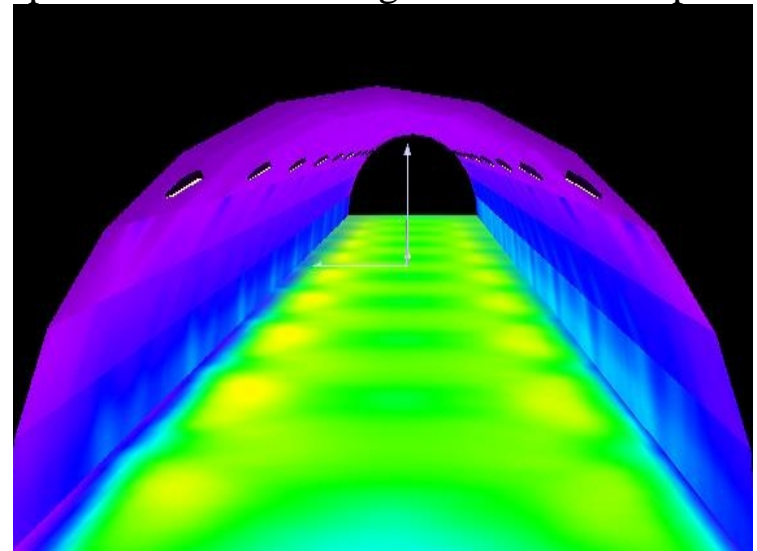

Figure 5 Simulation of pseudo color image with better lighting effect

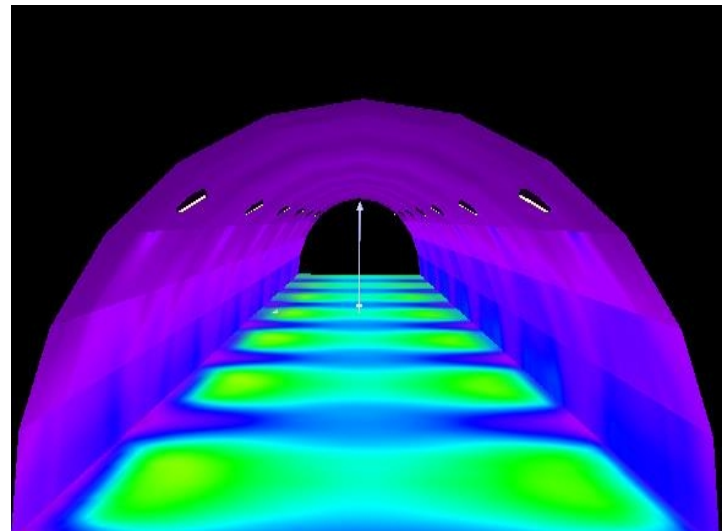

Figure 6 Simulation of pseudo color image with worse lighting effect 


\section{The Effect of Lighting Arrangement in Tunnel Lighting}

According tunnel lighting specification, three commonly used lighting arrangements are bilateral symmetry lighting arrangement, bilateral staggered lighting arrangement and midline lighting arrangement. Some tunnel engineering also adopt the way of bias lighting arrangement, such as Tunnel 1 in TeiFeng from WanZhou in ChongQing to KaiXian on the highway which achieved good energy saving effect ${ }^{[6]}$. This article made a research on simulation analysis for the three lighting arrangements in the specification.

According specification, basic lighting luminance of ChiBai Tunnel is to be achieved $2.5 \mathrm{~cd} / \mathrm{m}^{2}$. Simulation experiment shows that the luminance can be achieved by bilateral symmetry lighting arrangement with a $10 \mathrm{~m}$ interval or midline lighting arrangement with a $5 \mathrm{~m}$ interval. Thus, ways of bilateral symmetry lighting arrangement and bilateral staggered lighting arrangement both need 16 LED lamps with 30W while the way of midline lighting arrangement needs 16 LED lamps with 30W. The installation angle of bilateral symmetry lighting arrangement and bilateral staggered lighting arrangement is $30^{\circ}$.Due to a slight gap because of different mesh length, in order to reduce error, we adopt different mesh length to compute, including $30 \mathrm{~m}, 45 \mathrm{~m}, 60 \mathrm{~m}, 75 \mathrm{~m}$. The width and length of grid point is respectively $0.1666 \mathrm{~m}$ and $0.609 \mathrm{~m}$. The effect of the three lighting arrangement is showed in the table $1-3$.

Table1 The effect of bilateral symmetry lighting arrangement in tunnel lighting

\begin{tabular}{cccccc}
\hline $\begin{array}{c}\text { calculation } \\
\text { network length } / \mathrm{m}\end{array}$ & $\begin{array}{c}\text { average surface } \\
\text { illumination/lux }\end{array}$ & $\begin{array}{c}\text { minimum } \\
\text { illumination /lux }\end{array}$ & $\begin{array}{c}\text { maximum } \\
\text { illumination/lux }\end{array}$ & evenness & $\begin{array}{c}\text { average } \\
\text { brightness } / \mathrm{cd} / \mathrm{m}^{2}\end{array}$ \\
\hline 30 & 33 & 22 & 44 & 0.66 & 2.84 \\
45 & 33 & 22 & 44 & 0.66 & 2.84 \\
50 & 33 & 22 & 44 & 0.66 & 2.84 \\
78 & 32 & 15 & 44 & 0.48 & 2.75 \\
\hline
\end{tabular}

Table2 The effect of bilateral staggered lighting arrangement in tunnel lighting

\begin{tabular}{cccccc}
\hline $\begin{array}{c}\text { calculation } \\
\text { network length } / \mathrm{m}\end{array}$ & $\begin{array}{c}\text { average surface } \\
\text { illumination/lux }\end{array}$ & $\begin{array}{c}\text { minimum } \\
\text { illumination /lux }\end{array}$ & $\begin{array}{c}\text { maximum } \\
\text { illumination/lux }\end{array}$ & evenness & $\begin{array}{c}\text { average } \\
\text { brightness } / \mathrm{cd}^{\prime} / \mathrm{m}^{2}\end{array}$ \\
\hline 30 & 33 & 20 & 44 & 0.62 & 2.84 \\
45 & 33 & 20 & 44 & 0.62 & 2.84 \\
50 & 33 & 16 & 44 & 0.50 & 2.84 \\
78 & 32 & 7.02 & 44 & 0.22 & 2.75 \\
\hline
\end{tabular}

Table3 The effect of midline lighting arrangement in tunnel lighting

\begin{tabular}{cccccc}
\hline $\begin{array}{c}\text { calculation } \\
\text { network length } / \mathrm{m}\end{array}$ & $\begin{array}{c}\text { average surface } \\
\text { illumination/lux }\end{array}$ & $\begin{array}{c}\text { minimum } \\
\text { illumination /lux }\end{array}$ & $\begin{array}{c}\text { maximum } \\
\text { illumination/lux }\end{array}$ & evenness & $\begin{array}{c}\text { average } \\
\text { brightness } / \mathrm{cd}^{\prime} / \mathrm{m}^{2}\end{array}$ \\
\hline 30 & 31 & 28 & 32 & 0.92 & 2.66 \\
45 & 31 & 28 & 32 & 0.92 & 2.66 \\
50 & 31 & 28 & 32 & 0.91 & 2.66 \\
78 & 29 & 15 & 32 & 0.52 & 2.49
\end{tabular}

From the simulation results, uniformity of luminance is the highest in the way of midline lighting arrangement, followed by the way of bilateral symmetry lighting arrangement; Road luminance is substantially equal by the bilateral symmetry lighting arrangement and bilateral staggered lighting arrangement, followed by the way of midline lighting arrangement.

The model of entrance region 1 in ShiDao-YangCha Tunnel can be achieved basic luminance by 
30W LED lights with a $12 \mathrm{~m}$ interval. It can be achieved $105 \mathrm{~cd} / \mathrm{m}^{2}$ with $180 \mathrm{~W}$ LED lights with a $8 \mathrm{~m}$ interval and 400W HPS with a $4 \mathrm{~m}$ interval. There are different mesh length, including $18 \mathrm{~m}, 28 \mathrm{~m}$, $38 \mathrm{~m}, 48 \mathrm{~m}$. The width and length of grid point is respectively $0.183 \mathrm{~m}$ and $0.374 \mathrm{~m}$. Among them, it adopts 8 LED lights with 30W, 12 LED lights with $180 \mathrm{~W}$ and 24 HPS lights with 400W by the way of bilateral symmetry cloth lamp; 7 LED lights with 30W, 11 LED lights with $180 \mathrm{~W}$ and 23 HPS lights with $400 \mathrm{~W}$ by the way of bilateral staggered cloth lamp; 8 LED lights with 30W, 12 LED lights with $180 \mathrm{~W}$ and 24 HPS lights with $400 \mathrm{~W}$ by the way of midline cloth lamp. Mounting height and angle of bilateral symmetry cloth lamp and bilateral staggered cloth lamp is respectively $4 \mathrm{~m}$ and $25^{\circ}$.

Table4 Effect of bilateral symmetry lighting arrangement to the Tunnel

\begin{tabular}{cccccc}
\hline $\begin{array}{c}\text { calculation } \\
\text { network length } / \mathrm{m}\end{array}$ & $\begin{array}{c}\text { average surface } \\
\text { illumination/lux }\end{array}$ & $\begin{array}{c}\text { minimum } \\
\text { illumination /lux }\end{array}$ & $\begin{array}{c}\text { maximum } \\
\text { illumination/lux }\end{array}$ & evenness & $\begin{array}{c}\text { average } \\
\text { brightness } / \mathrm{cd} / \mathrm{m}^{2}\end{array}$ \\
\hline 18 & 1336 & 557 & 1761 & 0.42 & 114.8 \\
28 & 1327 & 539 & 1761 & 0.41 & 113.4 \\
38 & 1320 & 500 & 1764 & 0.38 & 113.4 \\
48 & 1260 & 256 & 1761 & 0.20 & 108.3 \\
\hline
\end{tabular}

Table5 Effect of bilateral staggered lighting arrangement to the Tunnel

\begin{tabular}{cccccc}
\hline $\begin{array}{c}\text { calculation } \\
\text { network length /m }\end{array}$ & $\begin{array}{c}\text { average surface } \\
\text { illumination/lux }\end{array}$ & $\begin{array}{c}\text { minimum } \\
\text { illumination /lux }\end{array}$ & $\begin{array}{c}\text { maximum } \\
\text { illumination/lux }\end{array}$ & evenness & $\begin{array}{c}\text { average } \\
\text { brightness } / \mathrm{cd}^{2} \mathrm{~m}^{2}\end{array}$ \\
\hline 18 & 1337 & 546 & 1779 & 0.41 & 114.9 \\
28 & 1331 & 544 & 1779 & 0.41 & 114.4 \\
38 & 1312 & 462 & 1775 & 0.35 & 112.7 \\
48 & 1217 & 205 & 1779 & 0.17 & 104.5 \\
\hline
\end{tabular}

Table6 Effect of midline lighting arrangement to the Tunnel

\begin{tabular}{cccccc}
\hline $\begin{array}{c}\text { calculation } \\
\text { network length /m }\end{array}$ & $\begin{array}{c}\text { average surface } \\
\text { illumination/lux }\end{array}$ & $\begin{array}{c}\text { minimum } \\
\text { illumination /lux }\end{array}$ & $\begin{array}{c}\text { maximum } \\
\text { illumination/lux }\end{array}$ & evenness & $\begin{array}{c}\text { average } \\
\text { brightness/cd/m }\end{array}$ \\
\hline 18 & 1348 & 632 & 1996 & 0.47 & 155.8 \\
28 & 1346 & 622 & 1996 & 0.46 & 155.7 \\
38 & 1333 & 541 & 1995 & 0.41 & 114.5 \\
48 & 1263 & 289 & 1996 & 0.23 & 108.5 \\
\hline
\end{tabular}

From the simulation results, uniformity of luminance is the highest in the way of midline lighting arrangement, followed by the way of bilateral symmetry lighting arrangement; Road luminance is the highest by the way of midline lighting arrangement, followed by the way of bilateral symmetry lighting arrangement.

By comparing simulation results of ChiBaiTunnel with Tunnel ShiDaoYangCha's, it shows that the height and the complexity of lighting combinations are different from each other because of different tunnel models, so they are suitable for different lighting arrangement. Thus, we can find suitable lighting arrangement by camparing luminance and uniformity of luminance when using Dialux software to simulate different tunnels. In addition, the selection of lighting arrangement is not only aiming at lighting effect, but also maintenance, stroboscopic and induction problems. Thus, in practical applications, in conformity with the lighting requirements, in order to choose suitbale lighting arrangement, lighting effect, energy-saving effect of lighting arrangement and the actual 
needs of the tunnel environment should be comprehensively considered.

\section{The Effect of Lighting Installation Location in Tunnel Lighting}

\section{The effect of installation height in tunnel lighting}

ChiBai tunnel middle segment model is designed with bilateral symmetry lighting arrangement, mounting angle is $30^{\circ}$, using 16 lamps of 30W LED (spacing 10m). Tables 7 and 8, respectively, indicates the effect of different installation height when selecting calculation network length of $78 \mathrm{~m}$ and $30 \mathrm{~m}$.

Table7 The effect of installation height for tunnel lighting with a calculation network length of $78 \mathrm{~m}$

\begin{tabular}{cccccc}
\hline $\begin{array}{c}\text { installation } \\
\text { height/m }\end{array}$ & $\begin{array}{c}\text { average surface } \\
\text { illumination/lux }\end{array}$ & $\begin{array}{c}\text { minimum } \\
\text { illumination /lux }\end{array}$ & $\begin{array}{c}\text { maximum } \\
\text { illumination/lux }\end{array}$ & evenness & $\begin{array}{c}\text { average } \\
\text { brightness } / \mathrm{cd}^{\prime} \mathrm{m}^{2}\end{array}$ \\
\hline 4 & 33 & 11 & 61 & 0.32 & 2.84 \\
5 & 32 & 15 & 44 & 0.48 & 2.75 \\
5.5 & 31 & 16 & 39 & 0.50 & 2.66 \\
6 & 31 & 15 & 36 & 0.48 & 2.66 \\
6.5 & 30 & 14 & 36 & 0.48 & 2.58 \\
7 & 30 & 12 & 38 & 0.41 & 2.58 \\
\hline
\end{tabular}

Table8 The effect of installation height for tunnel lighting with a calculation network length of $30 \mathrm{~m}$

\begin{tabular}{cccccc}
\hline $\begin{array}{c}\text { installation } \\
\text { height/m }\end{array}$ & $\begin{array}{c}\text { average surface } \\
\text { illumination/lux }\end{array}$ & $\begin{array}{c}\text { minimum } \\
\text { illumination /lux }\end{array}$ & $\begin{array}{c}\text { maximum } \\
\text { illumination/lux }\end{array}$ & evenness & $\begin{array}{c}\text { average } \\
\text { brightness } / \mathrm{cd}^{\prime} \mathrm{m}^{2}\end{array}$ \\
\hline 4 & 34 & 15 & 60 & 0.43 & 2.92 \\
5 & 33 & 22 & 44 & 0.66 & 2.84 \\
5.5 & 32 & 25 & 39 & 0.76 & 2.75 \\
6 & 32 & 25 & 36 & 0.79 & 2.75 \\
6.5 & 32 & 25 & 36 & 0.8 & 2.75 \\
7 & 31 & 20 & 38 & 0.66 & 2.66 \\
\hline
\end{tabular}

The model of entrance region 1 in the ShiDao-YangCha Tunnel is designed with bilateral symmetry lighting arrangement ,mounting angle is $25^{\circ}$, using 8 lamps of 30W LED(spacing 12m), 12 lamps 180W LED(spacing 8m), 24 lamps 400W HPS lamp(spacing 4m). Tables 9 and 10, respectively, indicates the effect of different installation height when selecting calculation network length of $78 \mathrm{~m}$ and $30 \mathrm{~m}$.

Table9 The effect of installation height for tunnel lighting with a calculation network length of $48 \mathrm{~m}$

\begin{tabular}{cccccc}
\hline $\begin{array}{c}\text { installation } \\
\text { height/m }\end{array}$ & $\begin{array}{c}\text { average surface } \\
\text { illumination/lux }\end{array}$ & $\begin{array}{c}\text { minimum } \\
\text { illumination /lux }\end{array}$ & $\begin{array}{c}\text { maximum } \\
\text { illumination/lux }\end{array}$ & evenness & $\begin{array}{c}\text { average } \\
\text { brightness/cd/m² }\end{array}$ \\
\hline 2.5 & 1330 & 199 & 2834 & 0.15 & 114.4 \\
3 & 1313 & 224 & 2142 & 0.17 & 112.8 \\
3.5 & 1288 & 245 & 1799 & 0.19 & 110.7 \\
4 & 1263 & 256 & 1761 & 0.20 & 108.5 \\
4.5 & 1222 & 247 & 1929 & 0.20 & 105.0 \\
\hline
\end{tabular}


Table10 The effect of installation height for tunnel lighting with a calculation network length of $30 \mathrm{~m}$

\begin{tabular}{cccccc}
\hline $\begin{array}{c}\text { installation } \\
\text { height/m }\end{array}$ & $\begin{array}{c}\text { average surface } \\
\text { illumination/lux }\end{array}$ & $\begin{array}{c}\text { minimum } \\
\text { illumination } \\
\text { /lux }\end{array}$ & $\begin{array}{c}\text { maximum } \\
\text { illumination/lux }\end{array}$ & evenness & $\begin{array}{c}\text { average } \\
\text { brightness } / \mathrm{cd}^{\prime} \mathrm{m}^{2}\end{array}$ \\
\hline 2.5 & 1377 & 650 & 2834 & 0.47 & 118.4 \\
3 & 1365 & 629 & 2142 & 0.46 & 117.3 \\
3.5 & 1345 & 607 & 1799 & 0.45 & 115.6 \\
4 & 1326 & 539 & 1761 & 0.41 & 114.0 \\
4.5 & 1289 & 494 & 1929 & 0.38 & 110.8 \\
\hline
\end{tabular}

From the simulation results, the lower of the installation height, the greater the average luminance is, and the uniformity has a different trend with different tunnel model, complexity of the lighting design, and computing grids.

\section{The effect of mounting angle in tunnel lighting}

ChiBai tunnel middle segment model is designed with bilateral symmetry lighting arrangement, installation height is 5m, using 16 lamps of 30W LED (spacing 10m). Tables 11 and 12, respectively, indicates the effect of different mounting angle when selecting calculation network length of $78 \mathrm{~m}$ and $30 \mathrm{~m}$.

Table11 The effect of mounting angle for tunnel lighting with a calculation network length of $78 \mathrm{~m}$

\begin{tabular}{cccccc}
\hline $\begin{array}{c}\text { installation } \\
\text { angle }{ }^{\circ}\end{array}$ & $\begin{array}{c}\text { average surface } \\
\text { illumination/lux }\end{array}$ & $\begin{array}{c}\text { minimum } \\
\text { illumination } \\
\text { /lux }\end{array}$ & $\begin{array}{c}\text { maximum } \\
\text { illumination/lux }\end{array}$ & evenness & $\begin{array}{c}\text { average } \\
\text { brightness } / \mathrm{cd}^{\prime} \mathrm{m}^{2}\end{array}$ \\
\hline 15 & 32 & 19 & 39 & 0.6 & 2.75 \\
20 & 32 & 19 & 41 & 0.58 & 2.75 \\
25 & 32 & 17 & 42 & 0.54 & 2.75 \\
30 & 32 & 15 & 44 & 0.48 & 2.75 \\
45 & 31 & 8.2 & 44 & 0.27 & 2.66 \\
50 & 30 & 6.69 & 44 & 0.22 & 2.58 \\
\hline
\end{tabular}

Table12 The effect of mounting angle for tunnel lighting with a calculation network length of of $30 \mathrm{~m}$

\begin{tabular}{cccccc}
\hline $\begin{array}{c}\text { installation } \\
\text { angle } /^{\circ}\end{array}$ & $\begin{array}{c}\text { average surface } \\
\text { illumination/lux }\end{array}$ & $\begin{array}{c}\text { minimum } \\
\text { illumination } \\
\text { /lux }\end{array}$ & $\begin{array}{c}\text { maximum } \\
\text { illumination/lux }\end{array}$ & evenness & $\begin{array}{c}\text { average } \\
\text { brightness } / \mathrm{cd}^{\prime} \mathrm{m}^{2}\end{array}$ \\
\hline 15 & 33 & 26 & 38 & 0.81 & 2.84 \\
20 & 33 & 26 & 41 & 0.78 & 2.84 \\
25 & 33 & 24 & 42 & 0.73 & 2.84 \\
30 & 33 & 22 & 44 & 0.66 & 2.84 \\
45 & 32 & 14 & 44 & 0.44 & 2.75 \\
50 & 31 & 13 & 44 & 0.43 & 2.66 \\
\hline
\end{tabular}


The model of entrance region 1 in the ShiDao-YangCha Tunnel is designed with bilateral symmetry lighting arrangements, installation height is $4 \mathrm{~m}$, using 8 lamps of 30W LED (spacing 12m), 12 lamps of 180W LED (Spacing 8m), 24 lamps of 400W HPS lamp(spacing 4m). Tables 13 and 14, respectively, indicates the effect of different mounting angle when selecting calculation network length of $78 \mathrm{~m}$ and $30 \mathrm{~m}$.

Table13 The effect of mounting angle for tunnel lighting with a calculation network length of of $48 \mathrm{~m}$

\begin{tabular}{cccccc}
\hline $\begin{array}{c}\text { installation } \\
\text { angle } /^{\circ}\end{array}$ & $\begin{array}{c}\text { average surface } \\
\text { illumination/lux }\end{array}$ & $\begin{array}{c}\text { minimum } \\
\text { illumination /lux }\end{array}$ & $\begin{array}{c}\text { maximum } \\
\text { illumination/lux }\end{array}$ & evenness & $\begin{array}{c}\text { average } \\
\text { brightness/cd/m }\end{array}$ \\
\hline 15 & 1289 & 309 & 1734 & 0.24 & 110.8 \\
20 & 1285 & 286 & 1752 & 0.22 & 110.4 \\
25 & 1263 & 256 & 1761 & 0.20 & 108.5 \\
30 & 1227 & 228 & 1766 & 0.19 & 105.5 \\
45 & 1077 & 175 & 1770 & 0.16 & 92.6 \\
50 & 1018 & 172 & 1745 & 0.17 & 87.5 \\
\hline
\end{tabular}

Table14 The effect of mounting angle for tunnel lighting with a calculation network length of of $30 \mathrm{~m}$

\begin{tabular}{cccccc}
\hline $\begin{array}{c}\text { installation } \\
\text { angle }{ }^{\circ}\end{array}$ & $\begin{array}{c}\text { average surface } \\
\text { illumination/lux }\end{array}$ & $\begin{array}{c}\text { minimum } \\
\text { illumination /lux }\end{array}$ & $\begin{array}{c}\text { maximum } \\
\text { illumination/lux }\end{array}$ & evenness & $\begin{array}{c}\text { average } \\
\text { brightness } / \mathrm{cd}^{\prime} / \mathrm{m}^{2}\end{array}$ \\
\hline 15 & 1351 & 715 & 1734 & 0.53 & 116.1 \\
20 & 1347 & 634 & 1752 & 0.47 & 115.8 \\
25 & 1326 & 539 & 1761 & 0.47 & 114.0 \\
30 & 1290 & 470 & 1766 & 0.36 & 110.9 \\
45 & 1136 & 365 & 1770 & 0.32 & 97.6 \\
50 & 1076 & 363 & 1745 & 0.34 & 92.5
\end{tabular}

From the simulation results, the smaller of the mounting angle, the greater the average luminance is, and the uniformity substantially is also better.

The effect of different combinations of power and space under a same power in a unit pitch length in tunnel lighting

ChiBai tunnel middle segment model is designed with bilateral symmetry lighting arrangement, installation height is $5 \mathrm{~m}$,mounting angle is $30^{\circ}$. Comparing the lighting effect of the different combinations when the lamp power is $30 \mathrm{~W}$, the spacing is $10 \mathrm{~m}$ and when the lamp power is $60 \mathrm{~W}$, spacing is $5 \mathrm{~m}$. Tables 15 and 16, respectively, indicates the effect of different combinations of power and distance when selecting calculation network length of $78 \mathrm{~m}$ and $30 \mathrm{~m}$.

Table15 The effect of different combinations of power and space under a same power in a unit pitch length in tunnel lighting with a calculation network length of $78 \mathrm{~m}$

\begin{tabular}{ccccccc}
\hline $\begin{array}{c}\text { lamp } \\
\text { power/W }\end{array}$ & $\begin{array}{c}\text { Lamp } \\
\text { number }\end{array}$ & $\begin{array}{c}\text { average surface } \\
\text { illumination/lux }\end{array}$ & $\begin{array}{c}\text { minimum } \\
\text { illumination/lux }\end{array}$ & $\begin{array}{c}\text { maximum } \\
\text { illumination/lux }\end{array}$ & $\begin{array}{c}\text { average } \\
\text { evenness }\end{array}$ & $\begin{array}{c}\text { brightness/cd/m } \\
2\end{array}$ \\
\hline 30 & 16 & 32 & 15 & 44 & 0.48 & 2.75 \\
60 & 8 & 33 & 4.97 & 76 & 0.15 & 2.84 \\
\hline
\end{tabular}


Table16 The effect of different combinations of power and space under a same power in a unit pitch length in tunnel lighting with a calculation network length of $30 \mathrm{~m}$

\begin{tabular}{ccccccc}
\hline $\begin{array}{c}\text { lamp } \\
\text { power/W }\end{array}$ & $\begin{array}{c}\text { Lamp } \\
\text { number }\end{array}$ & $\begin{array}{c}\text { average surface } \\
\text { illumination/lux }\end{array}$ & $\begin{array}{c}\text { minimum } \\
\text { illumination/lux }\end{array}$ & $\begin{array}{c}\text { maximum } \\
\text { illumination/lux }\end{array}$ & $\begin{array}{c}\text { average } \\
\text { evenness }\end{array}$ & $\begin{array}{c}\text { brightness/cd/m } \\
2\end{array}$ \\
\hline 30 & 16 & 33 & 22 & 44 & 0.66 & 2.84 \\
60 & 8 & 39 & 8.8 & 77 & 0.23 & 3.35
\end{tabular}

The model of entrance region 1 in the ShiDao-YangCha Tunnel is designed with bilateral symmetry lighting arrangement, installation height is $4 \mathrm{~m}$, mounting angle is $25^{\circ}$. Comparing the lighting effect of using 8 lamps of 30W LED(Spacing 12m) and using 4 lamps of 60W LED (Spacing $4 \mathrm{~m}$ ). Additionally, both is equipped with 12 lamps of 180W LED (Spacing 8m) and 24 lamps of 400W HPS lamps (spacing 4m). Tables 15 and 16, respectively, indicates the effect of different combinations of power and distance when selecting calculation network length of $78 \mathrm{~m}$ and $30 \mathrm{~m}$.

Table17 The effect of different combinations of power and space under a same power in a unit pitch length in tunnel lighting with a calculation network length of $48 \mathrm{~m}$

\begin{tabular}{ccccccc}
\hline $\begin{array}{c}\text { lamp } \\
\text { power/W }\end{array}$ & $\begin{array}{c}\text { Lamp } \\
\text { number }\end{array}$ & $\begin{array}{c}\text { average surface } \\
\text { illumination/lux }\end{array}$ & $\begin{array}{c}\text { minimum } \\
\text { illumination /lux }\end{array}$ & $\begin{array}{c}\text { maximum } \\
\text { illumination/lux }\end{array}$ & $\begin{array}{c}\text { average } \\
\text { evenness } \\
\text { brightness/cd/m² }\end{array}$ \\
\hline 30 & 8 & 1263 & 256 & 1761 & 0.203 & 108.5 \\
60 & 4 & 1265 & 252 & 1786 & 0.199 & 108.7 \\
\hline
\end{tabular}

Table18 The effect of different combinations of power and space under a same power in a unit pitch length in tunnel lighting with a calculation network length of $30 \mathrm{~m}$

\begin{tabular}{ccccccc}
\hline $\begin{array}{c}\text { lamp } \\
\text { power/W }\end{array}$ & $\begin{array}{c}\text { Lamp } \\
\text { number }\end{array}$ & $\begin{array}{c}\text { average surface } \\
\text { illumination/lux }\end{array}$ & $\begin{array}{c}\text { minimum } \\
\text { illumination /lux }\end{array}$ & $\begin{array}{c}\text { maximum } \\
\text { illumination/lux }\end{array}$ & evenness & $\begin{array}{c}\text { average } \\
\text { brightness/cd/m² }\end{array}$ \\
\hline 30 & 8 & 1326 & 539 & 1761 & 0.40648 & 114.0 \\
60 & 8 & 1336 & 543 & 1786 & 0.40644 & 114.8 \\
\hline
\end{tabular}

From the simulation results, the average luminance of the lamp power $30 \mathrm{~W}$ is smaller, and has a better uniformity.

\section{Conclusion}

The paper, through the establishment of the tunnel simulation model and simulation study on different lighting arrangements, the installation height, mounting angle and combination of different power and space, concluded that:

(1) When the tunnel lighting uses midline lighting arrangement, the tunnel illumination uniformity significantly higher than that with the bilateral symmetry midline lighting arrangement and bilateral staggered midline lighting arrangement, and bilaterally symmetrical midline lighting arrangement is slightly higher than bilaterally staggered lighting arrangement; When the tunnel is a relatively simple model and high, the tunnel road illumination in bilateral symmetry lighting arrangement and bilateral staggered lighting arrangement is higher than that in midline lighting arrangement, however, when the tunnel lighting arrangement is more complex model and low, the road illumination of midline lighting arrangement is significantly higher than the other two lighting arrangements. Therefore, the choice of lighting arrangement, should consider the basic situation of the tunnel, including the length, width and the brightness standards of the lighting segment ; in the actual project, should also consider maintenance, aesthetics, strobe and induction other issues, then select the appropriate lighting arrangement.

(2) The lower the lighting installation height is, the greater the tunnel road illumination; when the 
tunnel model lighting arrangement is simple and high, with the lighting installation height decreases, the road illumination uniformity increased, Illumination uniformity and installation height is U-shaped distributing, the best position is between $5 \mathrm{~m}$ and $6.5 \mathrm{~m}$, but when the tunnel lighting arrangement is a more complex model and low, the height is less, changes in illumination uniformity occurs in a smaller area, considering the height of the vehicle itself, it can be designed according to the actual projects, to make the lamp play a better performance.

(3) The smaller the angle of the lighting installation, the greater the road illumination, and illumination uniformity substantially increasing. Taking into account the impact of mounting height and the driver's vision, should try to make the installation angle of the lamp fixture that can be adjusted to direct the side of the road center line and the middle lane road.

(4) In the case of tunnel lighting power is equal, if the power is small and space is big ,road illumination becomes smaller, but uniformity is better. It can be selected according to the actual needs of the project.

(5) From the overall data of the two tunnels model simulation analysis, the more of the kinds of light, the worse of the uniformity is. Therefore, in the case of conformity with standard tunnel illumination, tunnel lighting design should be tried to avoid a variety of lamps, chosen combination should be simple and easy to install, and as beautiful as possible.

\section{References}

[1] JTG/TD70/2-01-2014, Road tunnel lighting design rules [S]. The Ministry of Communications of the People's Republic of China.

[2] Jin Shaochen. Simulation design of tunnel lighting based on DIAlux [J]. Internet of Things Technology, 2013,10:26-28.

[3] Tang Xin. Application of DIALux software in the design of tunnel lighting dimming [J]. Technology of Road Traffic , 2016,01:126-129.

[4] Chen Dan, Zhao Ning. Research on highway tunnel lighting design based on DIAlux [J]. Internet of Things Technology, 2015,04:107-108.

[5] Zhang Shanwei. The applicability and modeling method of DIALux in the design of highway tunnel lighting [J]. Lighting Engineering Journal, 2014,05:93-97.

[6] Qu Zhihao and Guangyou Tan, Deng Xin. Highway tunnel energy saving type dome side offset single light band lighting scheme [J]. Lamps and Lighting, 2008,32 (1): 30-35.

[7] Fan Shijuan, Yang Chao. Influence of lighting arrangement on tunnel lighting [J]. Journal of Jinggangshan University (NATURAL SCIENCE EDITION), 2013,03:50-53. 